Florida International University FIU Digital Commons

\title{
Further evidence for the relationship between eating frequency, body mass index, and physical activity
}

Mona Jahjah Ashchi

Florida International University

DOI: $10.25148 /$ etd.FI14032359

Follow this and additional works at: https://digitalcommons.fiu.edu/etd

Part of the Dietetics and Clinical Nutrition Commons

\section{Recommended Citation}

Ashchi, Mona Jahjah, "Further evidence for the relationship between eating frequency, body mass index, and physical activity" (2000). FIU Electronic Theses and Dissertations. 1327.

https://digitalcommons.fiu.edu/etd/1327 
FLORIDA INTERNATIONAL UNIVERSITY

Miami, Florida

FURTHER EVIDENCE FOR THE RELATIONSHIP BETWEEN EATING

FREQUENCY, BODY MASS INDEX, AND PHYSICAL ACTIVITY

A thesis submitted in partial fulfillment of the

requirements for the degree of

MASTER OF SCIENCE

in

DIETETICS AND NUTRITION

by

Mona Jahjah Ashchi

2000 
To: Dean Ronald M. Berkman

College of Health and Urban Affairs

This thesis, written by Mona Jahjah Ashchi, and entitled Further Evidence for the Relationship Between Eating Frequency, Body Mass Index, and Physical Activity, having been approved in respect to style and intellectual content, is referred to you for judgment.

We have read this thesis and recommend that it be approved.

Valerie George

Jorge Monserrate

Victoria Hammer Castellanos, Major Professor

Date of Defense: September 28, 2000

The thesis of Mona Jahjah Ashchi is approved.

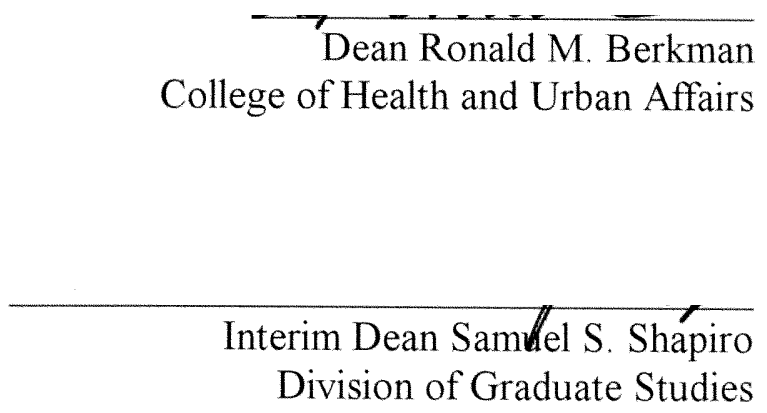

Florida International University, 2000 
ABSTRACT OF THE THESIS

FURTHER EVIDENCE FOR THE RELATIONSHIP BETWEEN EATING FREQUENCY, BODY MASS INDEX, AND PHYSICAL ACTIVITY

by

Mona Jahjah Ashchi

Florida International University, 2000

Miami, Florida

Professor Victoria Hammer Castellanos, Major Professor

The relationship between the frequency of eating, physical activity and Body Mass Index (BMI) was investigated. Seventy five women, aged 24 to 55 , were recruited from Florida International University. Via interview, subjects provided information regarding demographics and habitual eating frequency over 24-hours, and completed both the Baecke Questionnaire of Habitual Physical Activity and the Health Insurance Plan of New York Questionnaire on Physical Activity. Pearson correlations and partial correlation coefficients were used to assess the relationship between eating frequency, physical activity, age, and BMI. Results revealed significant positive correlations between eating frequency and total physical activity scores, and leisure time physical activity scores, but not between eating frequency and physical activity on the job. Partial correlations suggest that there may be an effect of eating frequency on BMI both through an effect on physical activity and through another mechanism. These results suggest that more frequent eaters tend to be more physically active, which may partially explain why lower body weights is associated with more frequent eating. 


\section{TABLE OF CONTENTS}

CHAPTER

PAGE

I. INTRODUCTION AND RESEARCH QUESTIONS ..................

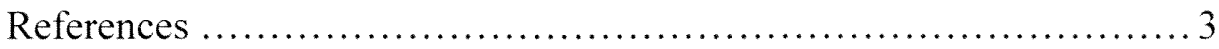

II. LITERATURE REVIEW ....................................... 5

Discovery of the Relationship Between Eating Frequency and Body Weight................................................... 5

Contemporary Studies of the Relationship between Meal Frequency and Adiposity 7

Possible Mechanisms to Explain an Inverse Relationship Between Eating Frequency and Adiposity.................................... 10

Conclusion......................................................... 19

References....................................................... 23

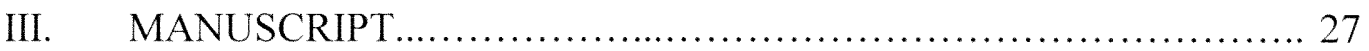

Introduction................................................... 27

Methods.........................................................28

Results........................................................ 30

Discussion..................................................... 37

Conclusion...................................................... 41

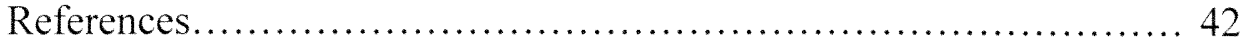

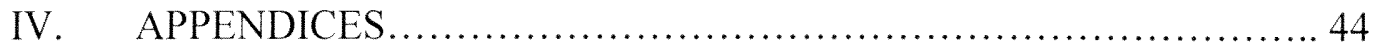




\section{CHAPTER I}

\section{INTRODUCTION AND RESEARCH QUESTIONS}

Feeding frequency has been cited as a factor that influences energy balance and adiposity. Although there is significant evidence that those who eat less frequently tend to have a higher body weight and greater adiposity (1-7), there is also some conflicting evidence $(8,9)$. Overall, studies have failed to elucidate the mechanism by which feeding frequency may effect energy balance in man.

In order to better understand the relationship between feeding frequency and body weight one must consider the factors that influence energy balance.

$(+/-)$ Energy Balance $=$ Energy Intake $(E I)-$ Energy Expenditure $(E E)$

Energy Intake $=$ kcalories consumed, and

Energy Expenditure $=$ Thermic Effect of Food $(\mathrm{TEF})+$ Basal Metabolic Rate $(\mathrm{BMR})+$ Physical Activity (PA)

Energy balance (or a stable body weight) occurs when energy intake (EI) equals energy expenditure (EE). An increase in energy storage or body weight (positive energy balance) occurs when EI exceeds EE.

Feeding frequency may potentially effect either or both, EI and EE. When studies have looked at the "EI" side of the energy balance equation, some have found that there is a tendency for a greater amount of food to be consumed (both grams and kcal) when a larger number of meals/snacks are eaten (10). This finding is actually counter to research which indicates that people tend to weigh less and have less body fat when they eat a larger number of meals (1-7). When studies have looked at the effect of eating frequency 
on the "EE" side of the energy balance equation, some research has found that eating more often does not effect either the TEF or the BMR (11-13), while other studies have found that the TEF is significantly higher while on a regimen of less frequent eating ( 14 , 15). Since TEF and BMR either do not change with meal frequency or are negatively correlated with meal frequency, changes in these variables do not explain reports that people who eat more often are less fat (1-7).

It has been hypothesized that a change in the third component of the "EE" side of the equation, PA, may account for the lower body weights and adiposity observed with high frequency of eating. A positive correlation between PA and the frequency of eating has been shown in one animal study (16), and has been implied in some other human studies $(17-20)$. Thus, the purpose of this study was to examine the relationship between frequency of eating and PA in humans.

\section{RESEARCH QUESTIONS:}

1. Is there a relationship between the frequency of eating and total PA ?

2. What is the nature of the relationship between Body Mass Index (BMI) and the frequency of eating? 


\section{REFERENCES}

1. Metzner $\mathrm{H}$, Lamphiear ED, Wheeler $\mathrm{CN}$, Larkin $\mathrm{AF}$. The relationship between frequency of eating and adiposity in adult women in the Tecumseh Community Health Study. Am J Clin Nutr 1977; 30:712-715

2. Ohlen A, Rossner S. Factors related to body weight changes during and after pregnancy: the Stockholm Pregnancy and Weight Development Study. Obes Res 1996; 4(3):271-276.

3. Cohn C, Shrago E, Joseph D. Effect of food administration on weight gain and body composition of normal and adrenalectomized rats. Am J Physiol 1955; 180:503-508.

4. Cohn C, Joseph D. Changes in body composition attendant on force-feeding. Am J Physiol 1959; 196:965.

5. Cohn C, Joseph D. Bell L, Oler A. Feeding frequency and protein metabolism. Am J Physiol 1963; 205(1):71-78.

6. Fabry P, Hijda S, Cerny K, Pechar J, Zvolankova K. Effect of meal frequency in school children, changes in weight-height proportions and skin-fold thickness. Am J Clin Nutr 1966; 18:358-361.

7. Fabry P, Hejl Z, Fodor J, Braun T. The frequency of meals, its relation to overweight, hypercholesterolemia, and decreased glucose tolerance. Lancet; 1964; 2:614-615.

8. Hawkins RC. Meal / snack frequencies of college students: a normative study. Behav Psychoth 1979; 7:85-90.

9. Edelstein SL, Barrett-Connor EL, Wingard DL, Cohn BA. Increased meal frequency associated with decreased cholesterol concentrations. A J Clin Nutr 1992; 55:664-69.

10. Hijda S, Fabry P. Frequency of food intake in relation to some parameters of the nutritional status. Nutrio et Dieta 1964; 6:216.

11. Kinabo DL, Durnin AGV. Effect of meal frequency on thermic effect of food in women. Euro J Clin Nutr 1990; 44:389-395.

12. Verboeket-Van de Venne GHPW, Westerterp RK, Kester MK. Effect of pattern of food intake on human energy metabolism. Brit J Nutr 1993; 70:103-115.

13. Dallosso MH, Murgatroyed RP, James TPW. Feeding frequency and energy balance in adult males. Hum Nutr: Clin Nutr 1982; 36C:25-39.

14. Tai M, Castillo P, Pi-Sunyer XF. Meal size and frequency: effect of nibbling versus 
gorging on the thermic effect of food (TEF) Am J Clin Nutr 1991; 54:783-787.

15. Verboeket-Van de Venne GHPW, Westerterp RK. Influence of feeding frequency on nutrient utilization in man: consequences for energy metabolism. Euro J Clin Nutr 1991; 45:161-169.

16. Leveille AG, $\mathrm{O}$ 'hea $\mathrm{KE}$. Influence of periodicity of eating on energy metabolism in the rat. J Nutr 1967; 93:541-545.

17. Butterworth DE, Neiman DC, Butler JV, Herring JL. Food intake patterns of marathon runners. Intern J Spr Nutr 1971; 173:1103-1107.

18. Kirsch KA, von Ameln H. Feeding patterns of endurance athletes. Euro J Appl Physiol 1981; 47:197-208.

19. Lindman AK. Eating and training habits of athletes: A balancing act. J Am Diet Assn 1990; 90:993-995.

20. Durrant ML, Royston P, Wloch RT. Effect of exercise on energy intake and eating patterns in lean and obese humans. Phsiol Behav 1982; 29:449-454. 


\section{CHAPTER II}

\section{LITERATURE REVIEW}

\section{INTRODUCTION:}

The relationship between the frequency of eating and energy balance has been investigated in a number of studies. Although there is significant evidence showing that those who eat less frequently tend to have higher body weight and adiposity (1-7), some conflicting evidence still exists $(8,9)$ and studies have failed to elucidate the mechanism by which feeding frequency effects energy balance in man.

\section{Discovery of the Relationship Between Eating Frequency and Body Weight:}

The relationship between feeding frequency and adipocity was first observed in the laboratory in rats (Cohn et al., 1955,) (3) (Table 1). The researchers observed that rats fed twice daily (gorgers) by a stomach tube, had almost double the amount of body fat of animals eating the same amount of the diet ad libitum (nibblers). At the end of the experiment, the nibbling rats had $9.6 \%$ body fat (down from $13.5 \%$ at the beginning of the experiment), compared with the tube-fed rats which had $17.6 \%$ body fat (up from $9.6 \%$ at baseline).

Cohn and colleagues were intrigued by the effect that the different feeding methodology had on body fat, but realized that the differences in body fat at the beginning of the experiment may have caused the force-fed animals to be overfed relative to the animals eating ad libitum. Subsequently Cohn et al., 1959, (4) repeated the experiment under appropriate conditions for "pair-feeding". One group of rats was force- 
fed the same amount of food consumed by the rats eating ad libitum. This time both groups had comparable initial body weights and body composition (at baseline, the forcefed rats weighed an average $152 \mathrm{~g}$ with $12.6 \mathrm{~g}$ body fat, and the rats eating ad libitum weighed an average $150 \mathrm{~g}$ with $14.9 \mathrm{~g}$ of body fat). At the end of the experiment, the nibbling rats had an average of 19.4 grams of body fat per rat compared to the gorging rats, which had an average of 25.8 grams of body fat per animal. Thus, although the "meal-eating" tube-fed rats received the same amount of food as did those eating ad libitum, the force-fed animals gained more body fat. No differences in body weight were reported.

About this same time in the early 1960 s, experiments which manipulated meal frequency in humans noted that frequency of eating affected serum lipids, glucose tolerance, and body weight. Gwinup et al., 1963, (10) reported a prompt decrease in serum lipid levels when meal frequency was changed from 3 meals per day to 10 meals per day, and a prompt increase when the pattern was changed from 3 meals per day to 1 meal per day. Thus, changes produced by nibbling were rapidly reversed by gorging and vice versa. These changes occurred in subjects with either hyperlipidemia or with normal serum lipid levels. In addition, in four subjects (out of five) there was a suggestion that weight loss tended to occur with nibbling and weight gain with gorging. Only in one subject, weight changes tended to occur in the opposite direction.

These experimental data were consistent with what was being observed in free living people. Several investigators observed an inverse relationship between meal frequency and adiposity. In 1964 Fabry et al. (7) studied 379 men between the ages of 60-64. In this study, the frequency of food intake was found to be negatively correlated with adiposity 
as measured by skin-fold thickness. Increased skin-fold thickness were significantly more common in those who consumed 3 or less meals a day compared to those who ate 5 or more meals a day. In addition, the incidence of overweight, hypercholesterolemia, and diminished glucose tolerance increased as the frequency of meals decreased. Hijda et al. (11) in 1964 reported a similar finding in an occupational group of 89 healthy men, aged 30-50. The subjects were divided into sub-groups according to their meal frequency. Among other findings, subjects with the smallest number of meals (including snacks) were found to be more overweight, and have thicker skin-folds than those subjects consuming 5-6 meals. Thus, just like the more experimentally controlled human and animal studies, studies in free-living humans also showed an inverse relationship between eating frequency and adiposity and body weight.

\section{Contemporary Studies of the Relationship between Meal Frequency and Adiposity:}

Since 1964 their have been a number of other studies supporting an inverse relationship between meal frequency and body weight. There have been basically two types of studies conducted: 1) those done under experimental conditions in which food intake is manipulated, and 2) studies which have examined feeding frequency in free living people (Table 2).

Metzner et al., 1977, (1) studied the relationship between the frequency of eating and adiposity in cross-sectional population of about 10,000 women 35-69 years of age. Trained interviewers administered a detailed 24-hour diet recall interview. Adiposity was based on an index using two skin-fold measurements, height, and weight. In this study, 
investigators found that the frequency of eating was inversely related to the adiposity index for both men and women.

A similar relationship has been observed in post-partum women. In the Stockholm Pregnancy and Weight Development Study, Ohlen et al., 1996, (2) reported that successful return towards pre-pregnancy weight occurred more often in women with regular breakfast and lunch habits (those not skipping meals) than in women with irregular breakfast and lunch habits (those skipping meals). Taken together, these two studies offer additional support of an inverse relationship between the frequency of eating and body weight and adiposity in free living humans.

Experimentally controlled studies have confirmed the findings of the early animal studies and the studies in free-living humans. Fabry et al., 1966 (6) systematically studied the effect of meal frequency in school children. Three Prague boarding schools with comparable number of children, equipment, and facilities for outdoor exercise were selected. Once a week the schools were visited by a dietitian who advised the catering staff on the preparation of a weekly menu, which was the same in all three schools. One school was advised to serve the food as 3 meals, the second school as 5 meals, and the third school as 7 meals. The feeding patterns were followed for one year, and during the holidays the parents were asked to adhere to the required feeding frequency whenever possible. Height, body weight, and skin fold thickness were measured at baseline and at one year. Among the 11-16 year olds in the school serving 3 meals per day, there was a significantly greater percentage of subjects in whom the weight-height proportionality changed in favor of body weight than in the other two schools serving 5 or 7 meals per day. In the school serving 3 meals per day, the increment of skin-fold thickness was also 
significantly greater compared with that found in children of similar age who ate 5 or 7 meals per day. Thus, meal frequency may have an effect on weight gain and adiposity in growing children as well as in adults.

In order to examine the effect of meal frequency with overfeeding, Mahler et al., 1972, (13) over-fed four young men with a liquid supplement (7.5 MJ/D) for 5 weeks. The rate of weight gain was significantly greater during the 3 weeks when the supplement was taken in one large meal in the evening compared with the 2 weeks when it was taken in 16 small doses at hourly intervals throughout the day. However, the gorging protocol always preceded the nibbling one, and this might have affected the results, as the energy requirement of the subjects would have increased over time as they gained weight and their BMI increased.

Although the studies, reviewed above, supported an inverse relationship between the frequency of eating and body adiposity, other studies have failed to demonstrate such a relationship. For example, Hawkins, 1979, (14) investigated the self-defined 'meal' and 'snack' frequencies of 240 normal-weight and overweight undergraduate students. In this study, four-day food records showed little association between weight and eating frequencies. Edelstein et al., 1992, (15) also found no relationships between eating frequency and BMI after administering a food frequency questionnaire to 800 subjects. However, limited response options ( 1 to 2,3, or 4 'meals and / or snacks' per day) may have considerably reduced observed variance in the population.

Despite the conflicting evidence, both, animal and free living human studies support an inverse relationship between the frequency of eating and body weight and adiposity. 


\section{Possible Mechanisms to Explain an Inverse Relationship Between \\ Eating Frequency and Adiposity:}

The above review provides evidence of an inverse relationship between the frequency of feeding, and adiposity and body weight in free living people. However, the mechanisms for this phenomenon are not understood.

$(+/-)$ Energy Balance $=$ Energy Intake $(E I)-$ Energy Expenditure $(E E)$

Energy Expenditure $=$ Thermic Effect of Food (TEF) + Basal Metabolic Rate (BMR) + Physical Activity (PA)

The following are possible mechanisms whereby increased meal frequency could reduce adiposity or body weight.

I. Increased eating frequency may reduce total EI.

II. Increased eating frequency may increase the TEF.

III. Increased eating frequency may increase BMR.

IV. Increased eating frequency may be associated with increased PA.

\section{Total Energy Intake and Meal Frequency:}

Energy intake (EI) includes calories from all food items and calorie beverages ingested. If lower EIs were associated with higher eating frequency, that would explain the lower body weights observed in frequent eaters. There is conflicting evidence regarding a relationship between EI and meal frequency.

Booth, 1988, (16) proposed that eating between 'meals' may be implicated in poor weight control, and suggested that caloric 'snacks' may fail to elicit appropriate satiety and compensatory response in subsequent 'meals' (poor appetite control), thereby 
contributing specifically to overeating and obesity. However, empirical evidence to support this is lacking.

In contrast to Booth, Westerterp-Plantenga et al., 1994, (17) suggested that improved short-term compensatory eating responses might arise from habitual 'snacking'. In a short-term study, they reported that habitual 'nibblers' (classified by eating frequency) made up the reduction in energy content of a light 'lunch' within 5 hours, while compensation by habitual 'gorgers' was not seen within 48 hours (17).

In a longer-term study, Hijda et al., 1964, (11) investigated whether a nibbling pattern of food intake promotes less total food consumption and consequently less total EI than a gorging pattern. In this study, the dietary pattern of an occupational group of 89 healthy men, aged 30-50 was evaluated, and the subjects were divided into sub-groups according to their meal frequency. Higher EI was reported in the subjects consuming their food in greater number of meals (5-6 or more). However, subjects with the smallest number of meals per day (3-4 including snacks) were found to be more overweight, and have thicker skin-folds than those consuming 5-6 meals. Skin-folds and weight values for subjects consuming 4-5 meals were intermediate.

Because it is well known that significant under-reporting occur in self reported dietary intake, especially by overweight people, the above study is certainly not conclusive evidence that feeding frequency does not affect total caloric intake. But, it can be said that this study does not support a mechanism of higher eating frequency resulting in lower adiposity through lower kcal intake.

In addition to the one study cited above, almost all of the more experimentally controlled studies, have controlled for EI, so that EI cannot be used to explain body 
weight differences. For example, Dallosso et al., 1982, (24) fed eight young adult males an isoenergetic diet of similar composition either in 2-meals (gorging) or in 6-meals/day (nibbling) for 2-weeks on each dietary regimen. The mean body weight at the end of the gorging period was $0.79 \mathrm{~kg}$ higher than at the start of the gorging period, but there was no significant difference between the body weight at the beginning and end of the nibbling period.

\section{Thermic Effect of Food and Eating Frequency:}

The thermic effect of food (TEF), also referred to as the diet-induced thermogenesis (DIT), represents the energy used in the body's processing of food. This includes work associated with the ingestion, absorption, transport, and storage of energy from ingested food. The percentage increase in energy expenditure over the BMR due to the TEF has been estimated to range from 5 to $15 \%(18,19)$. It is logical to theorize that if this energy "used in the body's processing of food" increases with increased meal frequency, it would explain the relationship between the frequency of eating and body weight and adiposity.

A number of studies have been conducted to investigate whether meal frequency has an effect on total EE through changes in the TEF. Kinabo et al., 1990, (20) investigated the effect of meal frequency and composition on the TEF in 18 non-obese female subjects. Eight subjects were given a high-carbohydrate low-fat diet once as a single meal and once as two meals. Ten other subjects consumed a low-carbohydrate high-fat diet once as a single meal and once as two meals. Their metabolic rate before and after consuming the test meal was measured by open circuit indirect calorimetry while the 
subjects were in the resting state (lying down). No significant differences were found between the two feeding regimens.

Other studies reported an increase in the TEF while on a gorging pattern of food intake. Tai et al., 1991, (21) found a significantly higher effect on the TEF when a set amount of food was given all at one time compared when it was given as 6 equal portions through the day ( $241 \mathrm{~kJ}$ above resting levels on the gorging pattern, versus $174 \mathrm{~kJ}$ on the nibbling pattern). Verboekket-van de Venne et al., 1991, (22), also in their study, reported a greater contribution of the TEF to 24-hour EE while on the gorging pattern of food intake. Thirteen subjects were fed to energy balance in 2-meals/day (gorging) and 7meals/day (nibbling) over a 2-day interval. They found increased lipogenic activity while on the gorging pattern, which resulted in an elevated EE during the postprandial hours. This indicated a greater contribution of the TEF to 24 hour EE. In a later study, Verboeket-Van de Venne et al., 1993, (23) found no effect of meal frequency on the contribution of TEF to the average daily metabolic rate.

In conclusion, these studies suggest an increase in meal frequency does not increase TEF. If there is any effect of feeding frequency on TEF, it is in the opposite direction. Thus, an increase in TEF does not seem to be the mechanism explaining the relationship between frequent eating and low body adiposity.

\section{Basal Metabolic Rate and Eating Frequency:}

The basal metabolic rate (BMR) reflects the energy needed to support life. For the calculation of BMR, measurements of oxygen consumption and carbon dioxide production are made under controlled conditions. Thus, an individual's BMR is determined when he or she is in a post-absorptive state (i.e., no food intake for at least 12 
hours), lying down, and completely relaxed (preferably very shortly after awakening from sleep in the morning). In addition, the temperature in the room in which the measurement occurs is made comfortable as possible for the individual (45).

Theoretically, an increase in BMR with increased meal frequency could account for the lower adiposity observed in frequent eaters. However, under controlled conditions, no differences have been reported in the BMR of nibblers versus gorgers. Verboeket-Van de Venne et al., 1993, (23) examined the effect of meal frequency on 10 males (25-61 years, BMI 20.7-30.4). During one week the subjects were fed to energy balance at 2meals/day, and during another week at 7-meals/day. A 36 hour stay in the respiration chamber followed the first 6-days of each feeding regimen. Oxygen consumption and carbon dioxide production were calculated over 24 hours. No statistical differences in 24hour EE were reported when people had a gorging versus nibbling pattern of food intake.

Dallosso et al., 1982, (24), also reported no discernible effect of meal frequency on EE in a whole body calorimeter. The authors studied feeding frequency and energy balance in adult males. Eight young adult males were fed isoenergetic diet of similar composition on either 2-meals or on 6-meals/day at defined times. On each dietary regimen of 2weeks the subjects occupied a whole body calorimeter for two, 31-hour periods, during which they followed a prescribed activity pattern. For each individual, the 24-hour EE in the calorimeter was highly reproducible and no discernible effect of meal frequency was observed under these controlled conditions. In summary, these studies suggest that BMR is not the factor explaining the relationship between the high feeding frequency and low body adiposity. 


\section{Physical Activity and Feeding Frequency:}

A greater EE through higher PA may account for the mechanism by which frequent eating is associated with less body fat. For this mechanism to work, both meal frequency and PA would have to be higher, apart from an increase in total EI. That is to say, an individual would have to eat more often and be more active, without eating more kcal, than a person who eats less often and exercises less.

One must consider the relationship between PA and total EI. Although, there is some evidence indicating that lean, active individuals increase their EI following exercise ( 25 , $26,27,38,29)$, overall, the body of evidence points to a rather weak coupling between PA-induced EE and total EI (30). In most studies, there is no observed increase in hunger or EI as a result of an exercise-induced energy deficit (31-34). For example, Imbeault et al., 1997, (31) put 11 lean young males on three activity regimens: exercise intensity at $30 \% \mathrm{VO}_{2} \max , 70 \% \mathrm{VO}_{2 m a x}$, and a control condition. Energy intake was measured using ad libitum test meals. Under these conditions, there was no effect of exercise on EI and hunger. Keim et al., 1990, (32) put 12 obese female subjects on three 18-day treatments of varying EE: sedentary, moderate exercise (increased daily expenditure by $12.5 \%$ ), and long duration exercise (increased daily expenditure by $25 \%$ ). Food intake was measured by pre-weighing. Here also, the investigators found no effect of exercise on EI. Thus, although increased PA may trigger increased EI following exercise, the body of evidence points to no change in total EI after PA induced EE.

The studies described above manipulated the activity level and its effect on total EI, but they did not look at the relationship between PA and feeding frequency. Drummond et al., 1996, (35) has suggested two possible relationships between feeding frequency and 
PA; (1) an active lifestyle may make people eat more often, and (2) an exerciser will have greater lean body mass which may explain why more frequent eating does not result in greater adiposity or body weight. A third possible relationship, not suggested by

Drummond et al, is that feeding frequency may effect PA level.

\section{Effect of Physical Activity on Eating Frequency:}

There is some evidence indicating that individuals with higher levels of PA may eat more frequently. Butterworth et al., 1994, (36) reported that marathon runners achieved a relatively high EI by eating frequently, rather than by consuming larger meals. These runners rarely missed 'main meals' and also frequently consumed 'snacks'. These results are also supported by other studies on the eating patterns of athletes $(37,38)$.

Increased eating frequency has also been observed in subjects adopting a quite modest increase in daily exercise (39). Durrant et al., 1982, (39) examined the effect of exercise on eating patterns in lean and obese subjects. Here, 12 obese and 4 lean subjects increased their EE by $100 \mathrm{kcal} /$ day by cycling on a bicycle ergometer, which represented a very small increase in net EE. This amount was deliberately chosen so that it can be easily accomplished by the subjects (approximately 30 -minutes). The researchers found that exercise significantly increased the frequency of eating an average of 0.5 bouts per day.

\section{Effect of Eating Frequency on Physical Activity:}

The only study to directly examine the relationship between eating frequency and PA, is an animal study by Leveille et al., 1967, (40). They looked at the spontaneous activity of meal-fed and rats eating ad libitum during the day and night. The spontaneous activity was determined by measuring the revolution of a wired cage. They found that the meal- 
fed animals had a significantly lower level of activity than the nibbling rats, particularly during the evening hours when activity was reduced by $75 \%$ in gorgers compared to the nibblers. The greater feed efficiency (i.e. weight gain per gram of food consumed) observed in the meal-fed rats, in this study was attributed to the lower activity level as compared to the nibbling rats. In another animal study, Fabry et al., 1963, (41) noted substantially lower oxygen consumption at night in intermittently starved rat, and they also concluded that changes in spontaneous PA in 'gorging' rats seemed to contribute to the apparent enhancement of feed efficiency on these regimens.

In humans, although it is possible hat a 'gorging' pattern of eating may be associated with reduced level of PA in free-living situations, Taylor at al., 1996, (42) did not see this being clearly demonstrated in calorimeter studies. Only indirect evidence exists for a relationship between meal frequency and PA in humans. Young, 1972, (43) reported on subjective responses of normal weight young men, after being put on 1 meal per day feeding regimen. Sixty percent of the men reported an overwhelming need to sleep after one large meal/day. This data suggests that gorging can cause a feeling of tiredness. One might speculate that this "overwhelming need to sleep" may result in less PA.

Verboeket-Van de Venne et al., 1993, (22) provided indirect evidence of decreased PA on a gorging pattern of eating. As described earlier, the investigators found a greater contribution of the TEF to 24-hour EE with the gorging pattern. But, because 24-hour EE was not affected by the feeding frequency, the researchers speculated that, while on the gorging pattern, EE during the rest of the day was decreased, possibly by a decrease in PA. That is, they hypothesized that PA must have been reduced at the same time that TEF was increased in order for total $\mathrm{EE}$ to be constant. 
Dallosso et al., 1982, (24) also has indirect evidence of increased PA in people on nibbling patterns compared to gorging patterns. In spite of the fact that there was no discernible effect of meal frequency on $\mathrm{EE}$ in the calorimeter (two, 31-hour periods) under controlled conditions, a progressive small weight gain was observed throughout the 2-week period on the 2-meals-a-day system. The mean body weight at the end of the gorging period was $0.79 \mathrm{~kg}$ higher than at the start of the 2 week gorging period ( $\mathrm{P}<$ 0.005), but there was no significant difference between the body weight at the beginning and end of the nibbling period. The investigators suggested that the increase in body weight may have been due to differences in PA throughout the day-time while subjects were not in the calorimeter. Thus, the investigators, suggest that increased frequency of eating may lead to changes in spontaneous PA.

The inability to measure a discrepancy between EI and energy output in the Dallosso study, illustrates how a small change in spontaneous activity could go unnoticed but still affect energy balance. Many factors may have an effect on spontaneous activity. Studies have shown that more 'frequent eaters' may have different lifestyle characteristics that may contribute to increased spontaneous PA. For example, Gallacher et al., 1988, (44), reported that 'Type A' behavior (characterized by time-driven conduct, a strong orientation towards work responsibilities or task completion and easily provoked hostility) has been associated with the consumption of small frequent meals. Eldestein $e t$ al., 1992, (15) surveyed over 800 subjects and found that lifestyle characteristics of frequent eaters might be quite different from those eating infrequently. They found that less frequent eaters were significantly younger, more likely to smoke, drank more alcohol, and had lower intakes of total energy and fat. 
Thus, direct evidence from one animal study, and indirect evidence from human studies suggest that an inverse relationship may exist between the frequency of eating and PA.

CONCLUSION: Although some conflicting evidence still exists, both epidemiological (especially the early ones) and experimental studies provide evidence of an inverse relationship between the frequency of eating and adiposity. Although more definitive research needs to be done concerning the "EI" side of the energy balance equation, preliminary research indicates that nibblers actually eat the same amount of energy as gorgers, if not more. When examining available evidence concerning each parameter of the "EE" side of the equation, neither changes in BMR nor changes in the TEF appear to offer an explanation for this phenomenon. However, the third component of EE, PA, has been shown to have a positive correlation with frequency of eating in one animal study, and has been implied in some other human studies.

Thus, the purpose of this study is to further investigate whether there is a relationship between the frequency of eating and activity level in humans. This study will not determine if eating frequency is causing changes in PA or, if activity is causing changes in food intake. Thus, the causality of any reported relationship should be the subject of subsequent investigations. 
TABLE 1: Nibbling and gorging, and snack/meal definitions in animal studies.

\begin{tabular}{|c|c|c|c|c|}
\hline GORGING & NIBBLING & A MEAL/SNACK & $\begin{array}{l}\text { STUDY } \\
\text { TYPE }\end{array}$ & OUTCOME \\
\hline Ad libitum & 2 & $\begin{array}{l}\text { The gorging rats were } \\
\text { pair-fed the same diet } \\
\text { consumed by the nibbling } \\
\text { rats through a stomach tube } \\
\text { twice a day (3) }\end{array}$ & Experimental & $\begin{array}{l}\text { The force-fed rats } \\
\text { contained almost double } \\
\text { the amount of body fat } \\
(17.6 \%) \text { as animals eating } \\
\text { the same diet ad libitum } \\
(9.6 \%) \text {. }\end{array}$ \\
\hline Ad libitum & 1 & $\begin{array}{l}\text { The gorging rats had access } \\
\text { to food from } 8 \text { am to } 10 \text { am } \\
\text { only, with water available at } \\
\text { all times }(42)\end{array}$ & Experimental & $\begin{array}{l}\text { The meal fed animals } \\
\text { had a significantly lower } \\
\text { level of activity than the } \\
\text { nibbling rats. }\end{array}$ \\
\hline Ad libitum & 2 & $\begin{array}{l}\text { The gorging rats were force- } \\
\text { fed the same diet consumed } \\
\text { by the nibbling rats twice a } \\
\text { day }(5)\end{array}$ & Experimental & $\begin{array}{l}\text { The fat content of the } \\
\text { force-fed animals relative } \\
\text { to those that ate ad libitum } \\
\text { became progressively } \\
\text { greater as the dietary } \\
\text { protein was increased in } \\
\text { quantity from } 0-67 \% \text { of the } \\
\text { diet. }\end{array}$ \\
\hline Ad libitum & 2 & $\begin{array}{l}\text { The gorging rats were force- } \\
\text { fed the same diet consumed } \\
\text { by the nibbling rats twice a } \\
\text { day (4) }\end{array}$ & Experimental & $\begin{array}{l}\text { The nibbling rats had an } \\
\text { average of } 4.5 \text { grams of fat } \\
\text { per rat compared to the } \\
\text { gorging rats, which had an } \\
\text { average of } 13.2 \text { grams of } \\
\text { fat. }\end{array}$ \\
\hline
\end{tabular}




\section{TABLE 2: Nibbling and gorging and snack/meal definitions in human studies.}

\begin{tabular}{|c|c|c|c|c|}
\hline NIBBLING & GORGING & A MEAL/SNACK & $\begin{array}{c}\text { STUDY } \\
\text { TYPE }\end{array}$ & OUTCOME \\
\hline 6 & 2 & $\begin{array}{l}\text { The } 2 \text { meals eaten at } 8 \text { hour } \\
\text { intervals, and the } 6 \text { meals } \\
\text { eaten at } 2 \text { hour intervals } \\
\text { (24) }\end{array}$ & Experimental & $\begin{array}{l}\text { No discernible effect of } \\
\text { meal frequency on EE was } \\
\text { reported in a whole body } \\
\text { calorimeter. }\end{array}$ \\
\hline $\begin{array}{l}\text { A range } \\
8 \text { to }\end{array}$ & 1 & $\begin{array}{l}\text { Starting with the first time } \\
\text { in the relevant } 24 \text {-hour } \\
\text { period, the components of } \\
\text { two or more successive } \\
\text { times are combined if these } \\
\text { times are within an hour of } \\
\text { each other and less than } 30 \text { - } \\
\text { minutes apart. The } \\
\text { combined intake was } \\
\text { counted as meal/snack if it } \\
\text { was } 40 \text { calories or more (1) }\end{array}$ & Observational & $\begin{array}{l}\text { The frequency of eating was } \\
\text { inversely related to the } \\
\text { adiposity index ( } 2 \text { skin-fold } \\
\text { measurements, height, and } \\
\text { weight) for both men and } \\
\text { women. }\end{array}$ \\
\hline 5 or more & 3 or less & (2) & Observational & $\begin{array}{l}\text { Successful return towards } \\
\text { pre-pregnancy weight } \\
\text { occurred more often in } \\
\text { women with regular } \\
\text { Breakfast and lunch habits } \\
\text { (those not skipping meals). }\end{array}$ \\
\hline 10 & 1 & $\begin{array}{l}\text { Based on the estimation } \\
\text { of energy required to } \\
\text { maintain the weight of each } \\
\text { subject, food was given as a } \\
\text { single meal in one period, or } \\
\text { as } 10 \text { equal meals every } 2 \\
\text { hours (10) }\end{array}$ & Experimental & $\begin{array}{l}\text { There was a prompt } \\
\text { decrease in serum lipid } \\
\text { levels when the meal pattern } \\
\text { was changed From } 3 \text {-meals } \\
\text { a day to nibbling, and a } \\
\text { prompt increase when it was } \\
\text { changed from } 3 \text {-meals a day } \\
\text { to gorging. }\end{array}$ \\
\hline 17 (snacks) & 1 & $\begin{array}{l}\text { The same diet given as } 1 \\
\text { Meal per day, or as } 17 \\
\text { snacks eaten at hourly } \\
\text { intervals throughout the day } \\
\text { (12) }\end{array}$ & Experimental & $\begin{array}{l}\text { Serum total and LDL } \\
\text { cholesterol and apolipo- } \\
\text { protein levels were lowered } \\
\text { by increasing meal } \\
\text { frequency alone with no } \\
\text { alteration in the nature or } \\
\text { amount of food eaten. }\end{array}$ \\
\hline 7 & 3 & $\begin{array}{l}\text { Caloric values of individual } \\
\text { meals (\%of total daily } \\
\text { caloric intake): } 12.8,7.0 \text {, } \\
1.1,35.4,13.4,21.5 \text {, and } 8.8 \\
\text { (6) }\end{array}$ & Experimental & $\begin{array}{l}\text { A greater percentage of the } \\
11-16 \text { year olds consuming } \\
3 \text { meals/day had increased } \\
\text { BMI and skin-fold } \\
\text { thickness, than those who } \\
\text { consumed } 7 \text { meals. }\end{array}$ \\
\hline
\end{tabular}




\begin{tabular}{|c|c|c|c|c|}
\hline 7 & 2 & $\begin{array}{l}\text { In the nibbling pattern, a } \\
\text { meal was a range of } 5 \% \text { to } \\
25 \% \text { of total EI ( } 23 \text { ) }\end{array}$ & Experimental & $\begin{array}{l}\text { No statistical differences } \\
\text { were reported in } 24 \text {-hour EE } \\
\text { when people had a gorging } \\
\text { versus nibbling pattern of } \\
\text { food Intake. }\end{array}$ \\
\hline 7 & 2 & $\begin{array}{l}\text { In the nibbling pattern, a } \\
\text { meal ranged from supplying } \\
5 \% \text { of total EI to } 25 \% \text { in no } \\
\text { more than } 21 / 2 \text { hours in- } \\
\text { between meals ( } 22)\end{array}$ & Experimental & $\begin{array}{l}\text { No effect of meal } \\
\text { frequency on the } \\
\text { contribution to DIT to the } \\
\text { average metabolic rate. }\end{array}$ \\
\hline 2 & 1 & \begin{tabular}{l}
\multicolumn{1}{c}{ A set amount of food } \\
given all at one time or as \\
two equal portions through \\
the day $(20)$
\end{tabular} & Experimental & $\begin{array}{l}\text { A significantly higher } \\
\text { effect on the TEF when the } \\
\text { food was given all at one } \\
\text { time. }\end{array}$ \\
\hline 6 & 3 & $\begin{array}{l}1400 \mathrm{kcal} \text { divided equally } \\
\text { between meals (11) }\end{array}$ & Experimental & $\begin{array}{l}\text { Higher El was reported in } \\
\text { the subjects consuming } \\
\text { their food in greater number } \\
\text { of meals. However, } \\
\text { subjects with the smallest } \\
\text { number of meals ( } 3-4 \\
\text { including snacks) per day } \\
\text { were found to be more } \\
\text { overweight, and to have } \\
\text { thicker skin-folds than those } \\
\text { with } 5-6 \text { meals. }\end{array}$ \\
\hline $\begin{array}{c}\text { No } \\
\text { Definition }\end{array}$ & $\begin{array}{c}\text { No } \\
\text { Definition }\end{array}$ & $\begin{array}{l}\text { Eating frequency } \\
\text { determined by using self- } \\
\text { defined 'meal' or 'snack' } \\
\text { (14). }\end{array}$ & Observational & $\begin{array}{l}\text { No significant associations } \\
\text { between measures of fatness } \\
\text { and numbers of eating } \\
\text { occasions were found. The } \\
\text { total number of eating } \\
\text { occasions was positively } \\
\text { associated with El in } \\
\text { females, which suggests } \\
\text { that more active women } \\
\text { were eating more frequently. }\end{array}$ \\
\hline
\end{tabular}




\section{REFERENCES}

1. Metzner H, Lamphiear ED, Wheeler $\mathrm{CN}$, Larkin AF. The relationship between frequency of eating and adiposity in adult men and women in the Tecumseh Community Health Study. Am J Clin Nutr 1977; 30:712-715.

2. Ohlen A, Rossner S. Factors related to body weight changes during and after pregnancy: the Stockholm Pregnancy and Weight Development Study. Obes Res $1996 ; 4(3): 271-276$.

3. Cohn C, Shrago E, Joseph D. Effect of food administration on weight gain and body composition of normal and adrenalectomized rats. Am J Physiol 1955; 180:503-508.

4. Cohn C, Joseph D. Changes in body composition attendant on force-feeding. Am J Physiol 1959; 196:965.

5. Cohn C, Joseph D, Bell L, Oler A. Feeding frequency and protein metabolism. Am J Physiol 1963; 205(I):71-78.

6. Fabry P, Hijda S, Cerny K, Osankova K, Pechar J, Zvolankova K. Effect of meal frequency in school children, changes in weight-height proportions and skin-fold thickness. Am J Clin Nutr 1966; 18:358-361.

7. Fabry P, Hejl Z, Fodor J, Braun T. The frequency of meals, its relation to overweight, hypercholesterolemia, and decreased glucose tolerance. Lancet $1964 ; 2: 614-615$.

8. Knittle JL. Meal eating vs. nibbling: effect on human adipose tissue metabolism. Am J Clin Nutr 1966 18:310.

9. Jones PJH, Namchuck GL, Pederson RA. Meal frequency influences circulating hormone levels but not lipogenesis rates in humans. Metabolism 1995; 44:218-223.

10. Gwinup G, Byron CR, Rouch HW, Kruger AF, Hamwi J. Effect of nibbling versus gorging on serum lipids in man. Am J Clin Nutr 1963 13:209-213.

11. Hijda S, Fabry P. Frequency of food intake in relation to some parameters of the nutritional status. Nutrio et Dieta 1964; 6:216.

12. Jenkins LA, Buckly G, Patten R, Singer W, Corey P, Josse GR. Nibbling versus gorging: metabolic advantages of increased meal frequency. N Engl J Med 1989; 321:929-34.

13. Mahler R. The relationship between eating and obesity. Acta Diabet Lat 1972; 9:449465 . 
14. Hawkins RC. Meal / snack frequencies of college students: a normative study. Behav Psyc 1979; 7:85-90.

15. Edelstein SL, Barrett-Connor EL, Wingard DL, Cohn BA. Increased meal frequency associated with decreased cholesterol concentrations. Am J Clin Nutr 1992; 55:66469.

16. Booth DA. Mechanisms from models - actual effect from real life: the zero-calorie drink-break option. Appetite 1988; 11(suppl): 94-102.

17. Westerterp-Plantenga MS, Wickmans-Duysens NA, ten Hoor F. Food intake in the daily environment after energy-reduced lunch, related to habitual meal frequency. Appetite 1994; 22: 173-182.

18. Daly JM, Haymsfield SB, Head CA, Harvey LP, Nixon DW, Katzeff H, Grossman GD. Human energy requirements: overestimation by widely used prediction equation. Am J Clin Nutr 1985; 42:1170-1174.

19. Owen OE, Kavle E, Owen ES, Polansky M, Capiro S, Mozzoli MA, Kendrick ZV, Bushman MC, Boden G. A reappraisal of caloric requirements in healthy women. Am J Clin Nutr 1986; 44:1-19.

20. Kinabo DL, Durnin AGV. Effect of meal frequency on thermic effect of food in women. Euro J Clin Nutr 1990; 44:389-395.

21. Tai M, Castillo P, Pi-Sunyer XF. Meal size and frequency: effect of nibbling versus gorging on the thermic effect of food (TEF). Am J Clin Nutr 1991; 54:783-787.

22. Verboeket-Van de Venne GHPW, Westerterp RK. Influence of the feeding frequency on nutrient utilization in man: consequences for energy metabolism. Euro J Clin Nutr $1991 ; 45: 161-169$.

23. Verboeket-Van de Venne GHPW, Westerterp RK, Kester MK. Effect of the pattern of food intake on human energy metabolism. Brit J Nutr 1993; 70:103-115.

24. Dallosso MH, Murgatroyed RP, James TPW. Feeding frequency and energy balance in adult males. Hum Nutr: Clin Nutr 1982; 36C:24-39.

25. Kissilef HR, Pi-Sunyer FX, Segel K. Acute effects of exercise on food intake in obese and non obese women. Am J Clin Nutr 1990; 52:240-45.

26. Durrant ML, Royston JP, Wloch RT. Effect of exercise on energy intake and eating patterns in lean and obese humans. Physiol Behav 1982; 29:449-54. 
27. Woo R, Pi-Sunyer FX. Effect of increased physical activity on voluntary intake in lean women. Metabolism 1985; 34:836-41.

28. Woo R, Garrow JS, Pi-Sunyer FX. Effect of exercise on spontaneous caloric intake in obesity. Am J Clin Nutr 1982; 36:470-77.

29. Woo R, Garrow JS, Pi-Sunyer FX. Voluntary food intake during prolonged exercise in obese women. Am J Clin Nutr 1982; 36:478-84.

30. Blundell J, King AN. Physical activity and regulation of food intake: current evidence. Med Sci Sport Exrc 1999; S573-S583.

31. Imbeault P, Saint-Pierre S, Almeras N, Tremblay A. Acute effects of exercise on energy intake and feeding behavior. Br J Nutr 1997; 77:511-521.

32. Keim NL, Barbieri FT, Van Loan DM, Anderson LB. Energy expenditure and physical performance in overweight women: response to training with and without caloric restriction. Metabolism 1990; 39:651-658.

33. King NA, Liuch A, Subbs JR, Blundell EJ. High dose exercise does not increase hunger or energy intake in free living males. Eur J Clin Nutr 1997; 51:478-483.

34. Kessileff HR, Pi-Sunyer FX, Segel K, Meltzer S, Foelsch AP. Acute effect of exercise on food intake in obese and non-obese women. Am J Clin Nutr 1990; 52:240-245.

35. Drummond S, Crombie N, Kirk T. Critique of the effect of snacking on body weight status. Euro J Clin Nutr 1996; 50:779-783.

36. Butterworth DE, Nieman DC, Butler JV, Herring JL. Food intake patterns of marathon runners. Intern J Sp Nutr 1994; 4:1-7.

37. Kirch KA, von Ameln H. Feeding patterns of endurance athletes. Euro J App Phys 1981; 47:197-208.

38. Lindman AK. Eating and training habits of triathletes: A balancing act. J Am Diet Ass. 1990; 90:993-995.

39. Durrant ML, Royston P, Wloch RT. Effect of exercise on energy intake and eating patterns in lean and obese humans. Phys Behav 1982; 29:449-454.

40. Leveille AG, O'hea KE. Influence of periodicity of eating on energy metabolism in the rat. J Nutr 1967; 93:541-545.

41. Fabry P, Petrasek R, Horakova E, Konopasek E, Braun T. Energy metabolism and growth in rats adapted to intermittent starvation. Br J Nutr 1963; 17: 295-301. 
42. Taylor MA, Garrow JS. The effect of meal frequency and energy restrictions on total energy expenditure and spontaneous activity in obese subjects in a chamber calorimeter. Proc Nutr Societ 1996; 55: 216A.

43. Young MC, Hutter FL, Scanlan SS, Rand EC, Lutwak L, Simko V. Metabolic effect of meal frequency on normal young men. Research 1972; 61:391-398.

44. Gallacher JEJ, Fehily AM, Yarnell JWG, Butland BK. Type A behavior, eating pattern, and nutrient intake: the Caerphilly study. Appetite 1988; 11:129-136.

45. Groff LJ, Gropper SS, Hunt MS. Advanced nutrition and human metabolism $\left(2^{\text {nd }}\right.$ edition). West Publishing Company 1995, St. Paul, MN; pp 466-467. 


\section{CHAPTER III}

\section{MANUSCRIPT}

\section{FURTHER EVIDENCE FOR THE RELATIONSHIP BETWEEN EATING FREQUENCY, BODY MASS INDEX, AND PHYSICAL ACTIVITY}

\section{INTRODUCTION}

The relationship between the frequency of eating and energy balance has been investigated in a number of studies. Although there is considerable evidence showing that individuals who eat less frequently tend also to have higher body weight and adiposity $(1,2,3,4,5,6,7)$, not all studies have revealed such a relationship $(8,9)$ and these studies have failed to elucidate the mechanism by which feeding frequency effects energy balance in man.

In order to investigate how eating frequency may affect energy balance in man, one must consider the factors affecting overall energy balance. Energy balance (+/-) equals EI minus EE. On the "EI" side of the energy balance equation, one study has found that there is a tendency for greater amount of food to be consumed (both grams and kcal) when a larger number of meals/snacks are eaten (10). This finding is actually counter to the observation that people tend to weigh less and have higher body adiposity when they eat a larger number of meals (1-7). Although more definitive studies need to be conducted on the relationship between meal frequency and overall food intake, there is currently no evidence that people who eat less frequently consume more energy. 
When examining available evidence concerning each parameter of the "EE" side of the equation, neither changes in BMR, nor changes in the TEF appear to offer an explanation for the higher BMI associated with less frequent eating $(11,12,13,14,15)$. However, the third component of EE, PA, has been shown to have a positive correlation with the frequency of eating in one animal study (16), and in several human studies, and differences in PA have been suggested as a possible explanation for the observed differences in BMI seen in association with more frequent eating $(13,14,17-20)$.

The objective of this study was to investigate the relationship between the frequency of eating and PA. In order to shed light on the possible mechanism of how eating frequency may be effecting total energy balance, we examined the relationship between frequency of eating and total PA, as well as PA on and off the job.

\section{METHODS:}

\section{Subjects}

Seventy five women in South Florida between the ages of 24 and 55 were recruited. Most subjects were faculty, employees, and graduate students at Florida International University. Subjects were recruited via university e-mails, flyers posted on campus, or were approached to take the interview while they were on the University's campus grounds (i.e. University cafeteria, and Department offices). Additional subjects were recruited from outside the University grounds via referrals. Subjects were excluded if they indicated that they had any chronic illness, were pregnant, or were dieting to lose or gain weight. 


\section{Study Design}

Potential subjects were first screened for eligibility (appendix A), then they signed a consent form (appendix B). All data were gathered via a questionnaire administered by an interviewer either in person or over the phone. Subjects provided information including age and self-reported height and weight, demographics, habitual eating patterns, and a recall of a typical 24-hour food intake (appendix C).

A "habitual meal frequency over 24-hours" (usual meal pattern) was used to determine the total number of eating occasions per day. Starting with the first eating occasion, the energy components of two or more successive times were combined if these were less than 30-minutes apart. The combined intake was counted as an "eating occasion" if it was 40 kcalories or more (1). For example, the subject reports having a coffee with milk and no sugar at 8:00 am, and at 8:20 am a piece of toast and cheese. This would be counted as one eating occasion because they were less than 30 minutes apart, and the combined intake was more than 40 k.calories. The typical number of eating occasions was confirmed by several questions which explored the usual eating frequency pattern. When a minor discrepancy occurred between the two numbers, the subject was asked to clarify it and a usual number of eating occasions was obtained. For example, one subject reported not having a lunch when answering the questions about her usual eating pattern, however, in her "habitual meal frequency" she reported consuming a series of snacks around lunch time which actually constituted two eating occasions.

Habitual PA was assessed through the use of two questionnaires. The Baecke Questionnaire of Habitual Physical Activity (Beacke) (appendix D) (21) provided the following physical activity scores: Total physical activity $=$ work index + sports index + 
non-sports index. The Health Insurance Plan of New York Questionnaire on Physical Activity (HIPNY) (appendix E) (22) provided the following scores: Total physical activity = occupational score + leisure score.

\section{Calculations and statistical analyses}

Body Mass Index (BMI) was calculated for each participant using the reported heights and weights $\left(\mathrm{BMI}=[\right.$ Body weight $(\mathrm{lb}) \times 705$.$\left.] / Height (\mathrm{In})^{2}\right)$. Pearson and partial correlation coefficients were used to assess the relationships between PA scores, eating frequency, age, and BMI.

\section{RESULTS:}

The mean age of the subjects was 40 (range 24-55 years). Table 3 provides the reported mean age, BMI, eating frequencies and physical activity scores of the participants.

With both questionnaires, significant positive correlations were found between total PA scores and the frequency of eating (Figure 1). Significant positive correlations were also found between leisure time and sports PA scores and the frequency of eating in both questionnaires (Table 4). However, significant correlations were not found between eating frequency and PA on the job using either questionnaire (Table 4).

Significant negative correlation was also obtained between BMI, and PA scores in both questionnaires (Table 4). Significant correlations were not found between age and total PA in either questionnaire (Table 4).

Using partial correlations, to determine the inter-relationships between BMI, age, physical activity, and eating frequency, we found that there were independent 
correlations between PA and BMI, and between eating frequency and BMI (Figure 2).

There was also a significant partial correlation between eating frequency and PA. 
Table 3

Mean Age, BMI, and PA scores of participants grouped by usual number of meals eaten per day.

\begin{tabular}{|c|c|c|c|c|c|c|c|c|c|c|}
\hline \multirow{2}{*}{$\begin{array}{l}\text { Eating } \\
\text { Frequency }\end{array}$} & \multirow{2}{*}{$\mathbf{N}(\%)$} & \multirow[t]{2}{*}{ Age } & \multirow[t]{2}{*}{$\underline{B M I}$} & \multicolumn{4}{|c|}{ Baecke Scores } & \multicolumn{3}{|c|}{ Health Ins. Scores } \\
\hline & & & & Work & Sport & Leisure & Total & Work & Leisure & Total \\
\hline 2 & $3(4)$ & 35.3 & 32.3 & 2.5 & 2.2 & 1.8 & 6.5 & 7.7 & 5.0 & 12.6 \\
\hline 3 & $16(21)$ & 45.8 & 29.1 & 2.1 & 1.9 & 2.4 & 6.3 & 6.2 & 4.5 & 10.6 \\
\hline 4 & $12(16)$ & 39.3 & 24.4 & 2.2 & 2.3 & 2.6 & 7.1 & 8.4 & 6.0 & 14.4 \\
\hline 5 & $21(28)$ & 40.1 & 24.0 & 2.4 & 2.6 & 2.7 & 7.7 & 9.2 & 7.4 & 16.6 \\
\hline 6 & $14(19)$ & 39.2 & 21.6 & 2.5 & 2.9 & 2.5 & 7.8 & 9.8 & 9.1 & 18.9 \\
\hline 7 & $6(8)$ & 35.2 & 21.6 & 2.2 & 3.0 & 2.6 & 7.9 & 8.7 & 8.2 & 16.8 \\
\hline 8 & $3(4)$ & 33.3 & 21.0 & 2.5 & 4.0 & 3.3 & 9.8 & 6.7 & 11.3 & 18.0 \\
\hline All & $75(100)$ & 40.2 & 24.7 & 2.3 & 2.5 & 2.6 & 7.4 & 8.3 & 7.0 & 15.3 \\
\hline
\end{tabular}


Table 4

Correlations between PA, eating frequency, BMI, and age.

\begin{tabular}{|c|c|c|c|c|c|c|c|c|c|}
\hline & $\begin{array}{l}\text { Baecke } \\
\text { Work }\end{array}$ & $\begin{array}{c}\text { Baecke } \\
\text { Sport }\end{array}$ & $\begin{array}{l}\text { Baecke } \\
\text { Leisure }\end{array}$ & $\begin{array}{c}\text { Baecke } \\
\text { Total }\end{array}$ & $\begin{array}{c}\text { HIPNY } \\
\text { Work }\end{array}$ & $\begin{array}{l}\text { HIPNY } \\
\text { Leisure }\end{array}$ & $\begin{array}{c}\text { HIPNY } \\
\text { Total }\end{array}$ & BMI & $\begin{array}{c}\text { Eating } \\
\text { Frequency }\end{array}$ \\
\hline $\begin{array}{l}\text { Eating } \\
\text { Frequency }\end{array}$ & $\begin{array}{l}r=0.169 \\
P=0.147\end{array}$ & $\begin{array}{l}r=0.554 \\
P=0.001\end{array}$ & $\begin{array}{l}r=0.273 \\
P=0.018\end{array}$ & $\begin{array}{l}r=0.519 \\
P=0.001\end{array}$ & $\begin{array}{l}r=0.183 \\
P=0.115\end{array}$ & $\begin{array}{l}r=0.659 \\
P=0.001\end{array}$ & $\begin{array}{l}r=0.489 \\
P=0.001\end{array}$ & $\begin{array}{l}r=-0.600 \\
P=0.001\end{array}$ & …........ \\
\hline BMI & $\begin{array}{l}r=-0.226 \\
P=0.051\end{array}$ & $\begin{array}{l}r=-0.453 \\
P=0.001\end{array}$ & $\begin{array}{l}r=-0.336 \\
P=0.003\end{array}$ & $\begin{array}{l}r=-0.508 \\
P=0.001\end{array}$ & $\begin{array}{l}r=-0.200 \\
P=0.085\end{array}$ & $\begin{array}{l}r=-0.495 \\
P=0.001\end{array}$ & $\begin{array}{l}r=-0.418 \\
P=0.001\end{array}$ & $\ldots$ & $\begin{array}{l}r=-0.600 \\
P=0.001\end{array}$ \\
\hline Age & $\begin{array}{l}r=-0.026 \\
P=0.825\end{array}$ & $\begin{array}{l}r=-0.048 \\
P=0.683\end{array}$ & $\begin{array}{l}r=0.048 \\
P=0.683\end{array}$ & $\begin{array}{l}r=-0.017 \\
P=0.882\end{array}$ & $\begin{array}{l}r=-0.042 \\
P=0.721\end{array}$ & $\begin{array}{l}r=0.088 \\
P=0.454\end{array}$ & $\begin{array}{l}r=0.011 \\
P=0.925\end{array}$ & $\begin{array}{l}r=0.281 \\
P=0.015\end{array}$ & $\begin{array}{l}r=-0.237 \\
P=0.041\end{array}$ \\
\hline
\end{tabular}


Figure 1: Eating Frequency and Physical Activity Scores in both questionares

- Baecke PA Score and Eating Frequency: $r=0.519, p<0.001$

$\nabla \quad$ HIP PA Score and Eating Frequency: $r=0.489, p<0.001$

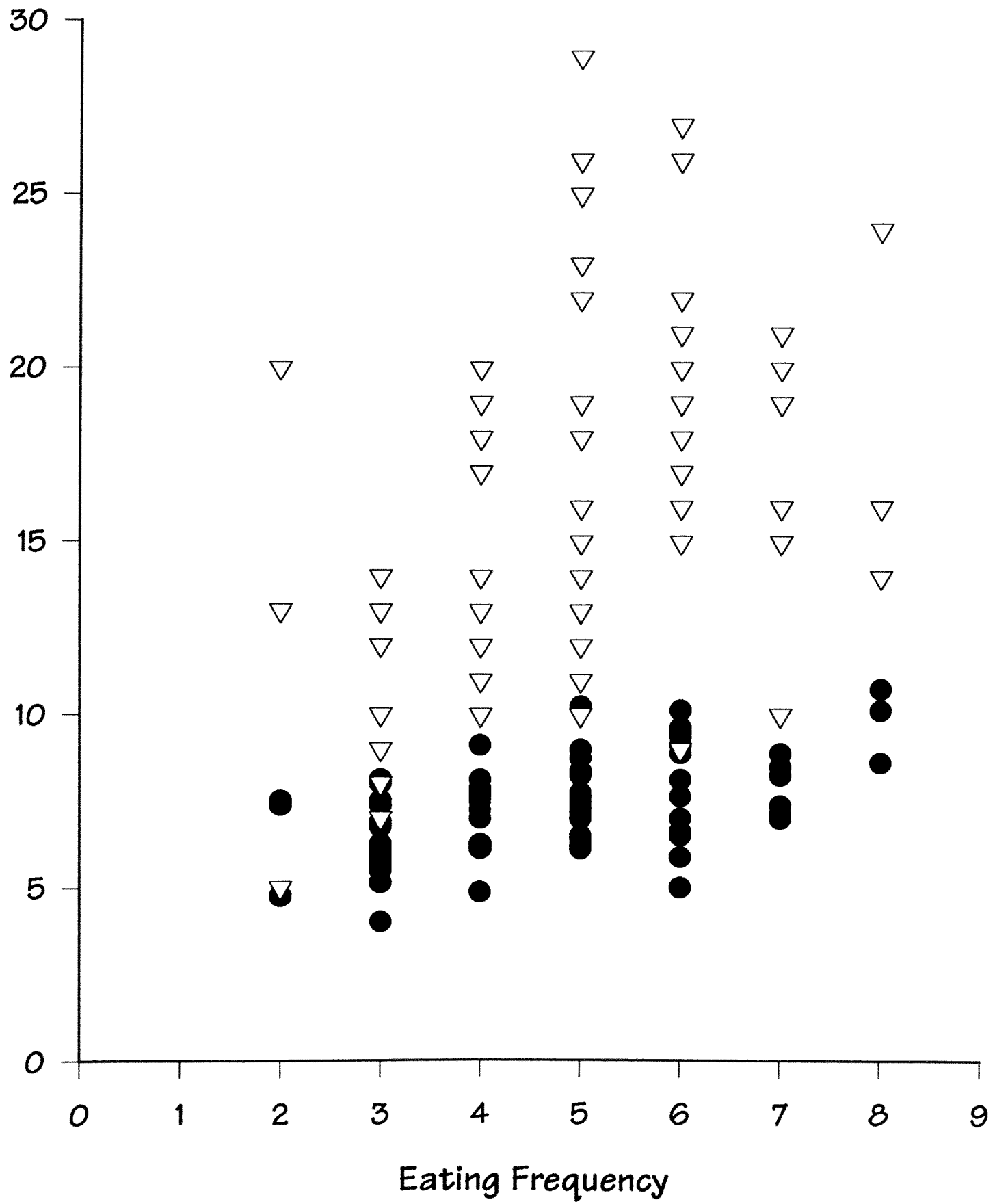


Figure 2: Partial correlation between measures of total physical activity, age, BMI, and eating frequency.

A. The Baecke Questionnaire of Habitual Physical Activity

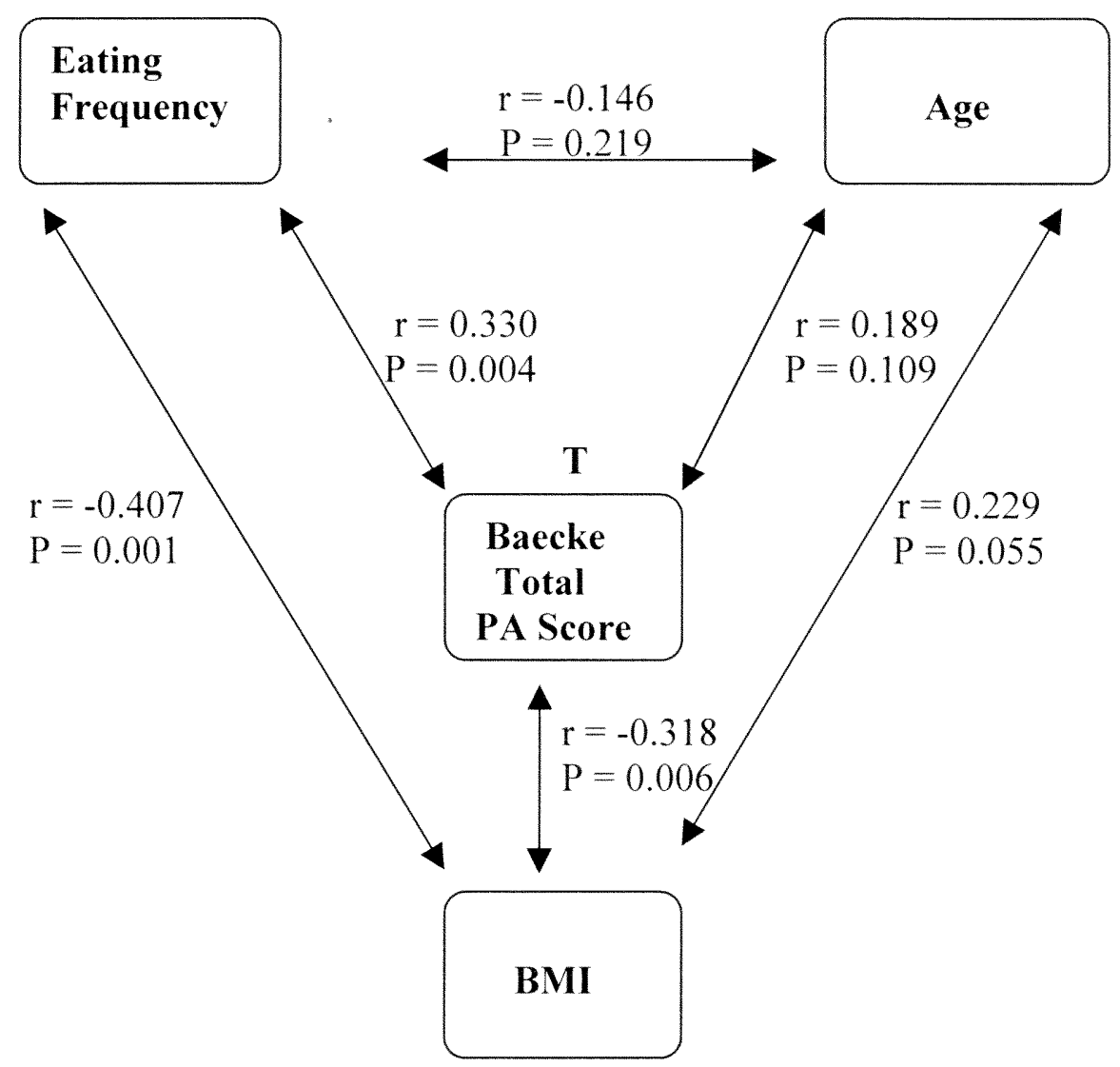


B. The Health Insurance Plan of New York Questionnaire on Physical Activity.

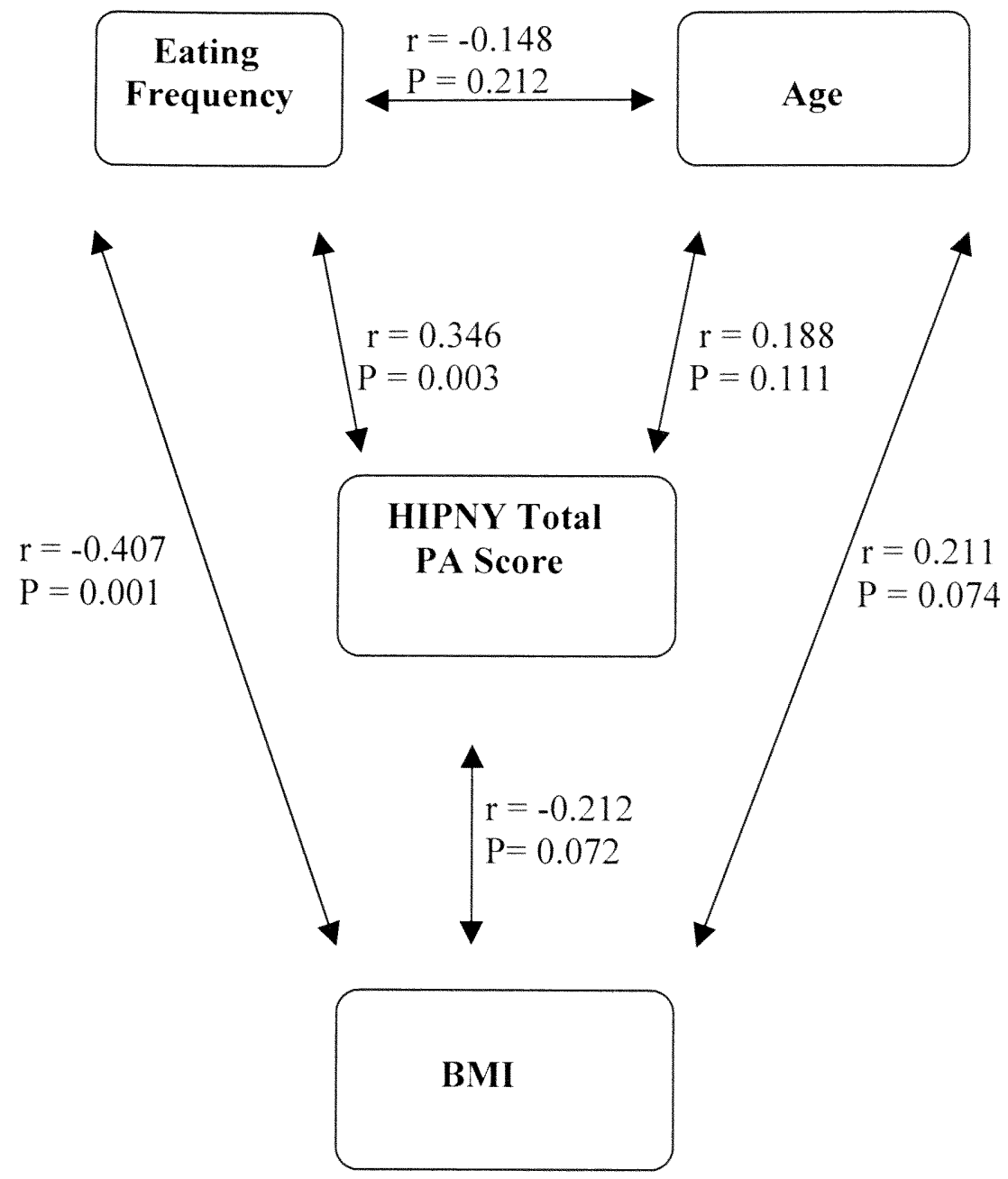




\section{DISCUSSION}

The results of this study confirm previous studies that have shown that increased meal frequency is associated with lower BMI (1-7). But, in this study we also found a significant positive correlation between eating frequency and PA. This is the first direct evidence of a relationship between eating frequency and PA in humans. This finding provides support for a number of other studies which had indirect evidence of such a relationship. The positive correlation between eating frequency and overall PA level obtained in this study may, at least in part, explain the negative correlation between eating frequency and BMI.

Several studies have reported indirect evidence that PA is higher in people with higher feeding frequency. Verboeket-Van de Venne et al., 1991, (14) found that the TEF was increased when fewer meals were ingested, yet 24-hour EE was not affected. Although the researchers did not measure PA, they hypothesized that EE from PA must have been decreased at the same time that TEF was increased in order for total EE to be constant. Dallosso et al., 1982, (13) also found indirect evidence of increased PA in people on nibbling patterns compared to gorging patterns. In this study, the researchers observed no discernible effect of meal frequency on EE measured in a calorimeter (two, 31-hour periods), yet a progressive small weight gain was measured throughout the 2-week period on the 2-meal-a-day system. The investigators suggested that a plausible explanation for an effect of food frequency on energy balance is that the frequency of eating leads to changes in spontaneous PA. The only published study which has direct evidence of a relationship between frequency of eating and PA, was done in rats. Leveille et al., 1967, (16), found that the meal-fed rats (fed twice daily) had a significantly lower level of 
activity than the nibbling rats (eating ad libitum). This was particularly true during the evening hours (the dark cycle) when the activity was reduced by $75 \%$ in gorgers compared to the nibblers. Although these studies were suggestive that PA and eating frequency may be correlated in humans, our study is the first to provide evidence of this relationship.

The nature of our study does not allow us to determine 'causality', that is, it does not explain the relationship between eating frequency and PA. There are several possible explanations for the relationship we have observed here. One theory is that expending energy throughPA may require increased eating frequency in order to achieve adequate energy intake. Several studies have noted that frequent eating in trained athletes is necessary to meet energy needs (18-20). But, probably more relevant to the current study, increased eating frequency has also been observed in human subjects adopting a modest increase in daily exercise (21). In this study, obese and lean subjects increased EE by 100 kcal per day by cycling on a bicycle ergometer. This increase in activity increased the number of eating bouts by an average of 0.5 bouts per day. The authors of this study felt that periods of cycling caused meals to be more fragmented. Thus, it is possible that leisure time activities, including sports, may cause people to eat more frequent, smaller meals. This theory is supported by the results of the current study in which we found a significant positive correlation between eating frequency and leisure and sport PA scores. Another theory that may explain the relationship between eating frequency and PA is that the eating pattern may affect the propensity to engage in PA. Young et al., 1972, (17) reported on subjective responses of normal weight young men that were put on a feeding regimen of one meal per day. In this study, sixty percent of the men reported an 
overwhelming need to sleep after one large meal. The researchers concluded that gorging can cause a feeling of tiredness and this "overwhelming need to sleep" may result in a reduction in PA. Thus, in this scenario, feeding frequency may be affecting activity level.

A third possible theory, that may explain the relationship between PA and eating frequency, is that personality type and lifestyle characteristics of frequent eaters might be quite different from those eating infrequently. For example, Edelstein et al., 1992, (9) found that less frequent eaters were significantly younger, more likely to smoke, drank more alcohol, and had lower intakes of total energy and fat. Gallacher et al., 1988, (24) also noted that 'Type A' behavior (characterized by time driven conduct, a strong orientation towards work responsibilities or task completion and easily revoked hostility) has been associated with the consumption of small frequent meals. This may suggest that people adopting certain lifestyles, or perhaps those with certain personality characteristics, may have the tendency to both eat more often and be more physically active. In our study, we did not collect information on personality type or lifestyle characteristics such as drinking or smoking, or diet composition. Further investigation into the relationship between personality type, lifestyle, PA, and eating frequency is warranted.

In this study, there was no evidence of a relationship between eating frequency and occupational PA. We found no significant correlation between eating frequency and PA level while on the job. It should be noted that we did not have a wide range of professions in our subject pool. Over $90 \%$ of the subjects in our study had professions where they worked in an office. On the job mobility and PA may be significantly limited by the job description and duties. It is possible that we would have found a correlation between on 
the job PA and eating frequency if women with high-activity professions had been included in the study.

Although previous studies have shown that PA levels change as people age $(25,26)$, we found no significant partial correlation between age and total PA using either questionnaire. This discrepancy with published studies may be an artifact of our relatively small subject pool used for the study $(75$ subjects, between 24 and 55 years of age), and the study population (over $90 \%$ are educated, and were either students, faculty, or doing office work). Thus, because we have such a homogenous group of subjects, differences in activity due to age may not be apparent.

Significant partial correlations were found between both eating frequency and BMI and between PA and BMI. This suggests that eating frequency has an impact on BMI apart from its effect on PA. This finding raises the question of whether eating frequency could be affecting BMI through two separate mechanisms, only one of which being related to $\mathrm{PA}$.

One limitation of this study is that we did not have a validated method to determine habitual meal frequency. We were forced to modify a standard "24-hour Recall" to be able to assess habitual eating frequency. This modification was necessary because $24-$ hour recalls are only valid to determine the habitual intake of populations, not of individuals (27). In future studies in this area, it is crucial that a validated tool to assess meal frequency be developed. A second possible limitation of the study is that the subjects heights and weights were self-reported. Miss-reporting or errors in these values would affect subsequent BMI calculations. Although self-reported values are not the 
ideal, self-reported heights and weights have been shown to be valid in other studies (28). Thus, the results of this study are unlikely to be affected by this methodology.

\section{CONCLUSION}

In our study, we found that people who ate more frequently also had higher PA levels, especially in leisure time activities and sports. More frequent eaters were also found to have lower BMI. Although this study provided information on the relationship between PA and meal frequency, it did not specifically investigate whether or not increased meal frequency drives PA or if increased PA causes an increase in meal frequency. Therefore, future studies should further investigate what specific mechanism may be responsible for the relationship.

This area of investigation has important implications for health promotion. If in the future, research shows that increasing eating frequency helps people to be more physically active, RD's may advise patients to eat smaller, more frequent meals to help them manage their weight and be more physically fit. On the other hand, if being more physically active drives changes in other lifestyle factors, such as meal size and frequency, exercise-promotion programs can help beginning exercisers cope with these lifestyle modifications. 


\section{References}

1. Metzner $\mathrm{H}$, Lamphiear ED, Wheeler $\mathrm{CN}$, Larkin $\mathrm{AF}$. The relationship between frequency of eating and adiposity in adult men and women in the Tecumseh Community Health Study. Am J Clin Nutr 1977; 30:712-715.

2. Ohlen A, Rossner S. Factors related to body weight changes during and after pregnancy: the Stockholm Pregnancy and Weight Development Study. Obes Res 1996; 4(3):271276.

3. Cohn C, Shrago E, Joseph D. Effect of food administration on weight gain and body composition of normal and adrenalectomized rats. Am J Physiol 1955; 180:503-508.

4. Cohn C, Joseph D. Changes in body composition attendant on force-feeding. Am J Physiol 1959; 196:965.

5. Cohn C, Joseph D, Bell L, Oler A. Feeding frequency and protein metabolism. Am J Physiol 1963; 205(I):71-78.

6. Fabry P, Hijda S, Cerny K, Osankova K, Pechar J, Zvolankova K. Effect of meal frequency in school children, changes in weigh-height proportions and skin-fold thickness. Am J Clin Nutr 1966; 18:358-361.

7. Fabry P, Hejl Z, Fodor J, Braun T. The frequency of meals, its relation to overweight, hypercholesterolemia, and decreased glucose tolerance. Lancet; 1964; 2:614-615.

8. Hawkins RC. Meal / snack frequencies of college students: a normative study. Behav Psyc 1979; 7:85-90.

9. Edelstein SL, Barrett-Connor EL, Wingard DL, Cohn BA. Increased eating frequency associated with decreased cholesterol concentrations. Am J Clin Nutr 1992; 55:664-69.

10. Hijda S, Fabry P. Frequency of food intake $n$ relation to some parameters of the nutritional status. Nutrio et Dieta 1964; 6:216.

11. Verboeket-Van de Venne GHPW, Westerterp RK, Kester MK. Effect of pattern of food intake on human energy metabolism. Brit J Nutr 1993; 70:103-115.

12. Kinabo DL, Durnin AGV. Effect of meal frequency on thermic effect of food in women. Euro J Clin Nutr 1990; 44:389-395.

13. Dallosso MH, Murgatroyed RP, James TPW. Feeding frequency and energy balance in adult males. Hum Nutr: Clin Nutr 1982; 36C:25-39. 
14. Verboeket-Van de Venne GHPW, Westerterp RK. Influence of feeding frequency on nutrient utilization in man: Consequences foe energy metabolism. Euro J Clin Nutr $1991 ; 45: 161-169$.

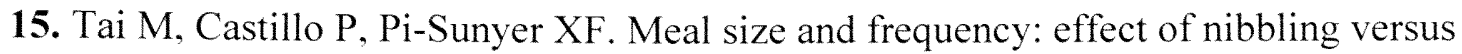
gorging on the thermic effect of food (TEF). Am J Clin Nutr 1991; 54:783-787.

16. Leveille $\mathrm{AG}, \mathrm{O}$ 'hea $\mathrm{KE}$. Influence of periodicity of eating on energy metabolism in the rat. J Nutr 1967; 93:541-545.

17. Young MC, Hutter FL, Scanlan SS, Rand EC, Lutwak L, Simko V. Metabolic effect of meal frequency on normal young men. Research 1972; 61:391-398.

18. Butterworth DE, Neiman DC, Butler JV, Herring JL. Food intake patterns of marathon runners. Intern J Spr Nutr 1994; 4:1-7.

19. Kirsch KA, von Ameln H. Feeding patterns of endurance athletes. Euro J Appl Physiol 1981; 47:197-208.

20. Lindeman $A K$. Eating and training habits of triathletes: A balancing act. J Am Diet Assoc 1990; 90:993-995.

21. Durrant ML, Royston P, Wloch RT. Effect of exercise on energy intake and eating patterns in lean and obese humans. Psych Behav 1982; 29:449-454.

22. Baecke JAH, Burema J, Frijters REJ. A short questionnaire for the measurement of habitual physical activity in epidemiological studies. Am J Clin Nure 1982; 36:936-942.

23. Shapiro S, Weinblatt E, Frank WC, Sager VR. The H.I.P. study of incidence and prognosis of coronary heart disease. J Chron Dis 1965; 18:527-558.

24. Gallacher JEJ, Fehily AM, Yarnell JWG, Butland BK. Type A behavior, eating pattern, and nutrient intake: the Caerphilly study. Appetite 1988; 11:129-136.

25. Yeager KK, Macera AC. Physical activity and health profiles of United States women. Clin Sp Med 1994; 13:329-335.

26. Pafenbarger SR, Kampert BJ, Lee, Hyde TR, Leung WR, Wing LA. Changes in physical activity and other life way patterns influencing longevity.

27. Allison D,B., ed.. Handbook of assessment methods for eating behaviors and weightrelated problems, P. 29. Sage Publications, Thousand Oaks, CA.

28. Stunkard AF, Albaum, JM. The accuracy of self-reported weights. Am J Clin Nutr $1982 ; 34: 1593-1599$. 


\section{Appendix: A}

\section{Screening Form}

1. Do you suffer from any disease or illness? Yes / No

2. If yes what?

3. Are you taking any medications, other than birth control, acne, or allergy medications? Yes / No

4. If Yes what?

5. What is your age?

6. Are you currently dieting to either lose or gain weight? Yes / No

7. If yes what diet are you following? 


\section{Appendix: B}

\section{Eating Frequency and Physical Activity Study Consent Form}

Principal Investigator: Mona J Ashchi, B.S., a graduate student working under the supervision of: Victoria H. Castellanos, Ph.D., R.D.

College of Health Sciences,

Florida International University

Procedure: The study involves an approximately 10-minute interview including 24-hour typical dietary recall, physical activity questionnaires, and some demographics.

Risks: There will be no risks involved during the interview, or while filling the questionnaires. All records will be kept confidential with no names or phone numbers identifying the records.

Benefits: As a participant, you will be contributing to our understanding of human food consumption patterns and its effects on physical activity.

Right to Withdraw: Participation in this study is completely voluntary. You may withdraw your consent and discontinue participation in this research project at any time with no negative consequences. You have the right to ask questions concerning the procedure and have any questions answered to your satisfaction.

Questions: If you desire further information about this research you should contact Mona J. Ashchi, B.S. at (305) 945-0001. Or Victoria Castellanos, Ph.D. at (305) 3483235. A copy of this informed consent will be provided to you.

I have read and I understand the above.

I FURTHER UNDERSTAND THAT I AM FREE TO WITHDRAW MY CONSENT AND TERMINATE PARTICIPATION AT ANY TIME.

Participant's Signature

Date

I have explained and defined in detail the research procedure in which the participant has agreed to participate, and have offered her a copy of this informed consent form. 


\section{Appendix: C}

\section{Demographics, and Habitual Meal Frequency over 24-Hours}
Age:
Height:
Weight:

1. What do you normally have for breakfast?

2. Do you normally have lunch? Yes / No

3. Do you normally have something in-between breakfast and lunch, other than tea, coffee, or diet soda? Yes / No

4. If yes, how many separate times do you eat something between breakfast and lunch (at least $1 / 2$ an hour in-between)? Describe typical :

5. Do you normally have dinner? Yes / No

6. Do you normally have something between lunch and dinner, other than coffee, tee, or diet soda? Yes / No

7. If yes, how many separate times do you have something between lunch and dinner (at least $1 / 2$ an hour in-between)? . Describe typical:

8. Do you normally have anything after dinner? Yes / No

9. If yes, list:

Habitual meal frequency over 24-hours

\begin{tabular}{|l|l|}
\hline Time: From:__ To & Food: \\
\hline & \\
\hline & \\
\hline & \\
\hline & \\
\hline
\end{tabular}




\section{Appendix: D}

(Page 1 of 2)

\section{Baecke Questionnaire of Habitual Physical Activity}

1. What is your main occupation?

$1=$ "low level" occupation such as office or clerical work, driving, shopping, teaching, or studying.

$2=$ "Middle level" occupation such as factory work, plumbing, or carpentry.

$3=$ "High level" occupation such as dock work or construction work.

2. At work I sit

never / seldom / sometimes / often / always

3. At work I stand

never / seldom / sometimes / often / always

$1-2-3-4-5$

4. At work I walk

never / seldom / sometimes / often / always

$1-2-3-4-5$

5. At work I left heavy loads

Never / seldom / sometimes / often / always

$1-2-3-4-5$

6. After working I am tired

never / seldom / sometimes / often / always

$1-2-3-4-5$

7. At work I sweat

never / seldom / sometimes / often / always

8. In comparison with others my own age I think my work is physically much heavier / heavier / as heavy / lighter / much lighter

9. Do you play sport

yes / no

if yes:

- which sport do you play most frequently?

Intensity $0.75-1.26-1.76$

-how many hours a week? $<1 / 1-2 / 2-3 / 3-4 />4$ Time $0.5-1.5-2.5-3.5-4.5$

-how many months a year? $<1 / 1-3 / 4-6 / 7-9 />9$ Proportion 0.04-0.17-0.42-

If you play a second sport:

$0.67-0.92$

-which sport do you play most frequently? Intensity $0.76-1.26-1.76$

-how many hours a week? $<1 / 1-2 / 2-3 / 3-4 />4$ Time $0.5-1.5-2.5-3.5-4.5$

-how many months a year? $<1 / 1-3 / 4-6 / 7-9 />9$ Proportion 0.04-0.17-0.42- 
10. In comparison with others my own age I think my physical activity during leisure time is

much more / more / the same / less / much less

11. During leisure time I sweat very often / often / sometimes / seldom / never

12. During leisure time I play sport never / seldom / sometimes / often / very often

13. During leisure time I watch television never / seldom / sometimes / often / very often

14. During leisure time I walk never / seldom / sometimes / often / very often

15. During leisure time I cycle never/seldom / sometimes / often / very often

16. How many minutes do you walk and/or cycle per day to and from work, school, and shopping?

$<5 / 5-15 / 15-30 / 30-45 />45$ 


\section{Appendix: E}

(Page 1 of 2)

\section{Health Insurance Plan of New York \\ Questionnaire}

\section{Physical Activity Connected with Job}

Question

Time on the job spent sitting
Practically all

More than $1 / 2$

About $1 / 2$

Less than $1 / 2$

Almost none
Answer

Assigned Weight

0

1

2

3

4

Almost none $\quad 0$

Less than $1 / 2$

About $1 / 2$

More than $1 / 2$

Practically all 4

Walking to get to and from work None or less than 1 block 1

1 or 2 blocks 2

3 or 4 blocks 3

5 to 9 blocks 4

20 to 39 blocks 5

$40+$ blocks $(2+$ miles $) \quad 6$

Lifting or carrying heavy things Very infrequently or never 0 Sometimes 3

Frequently 6

Transportation to and from work None 0

Car and/or bus and/or railroad and/or ferry 1 Subway 2

Subway and one or more other modes of transportation 3

Hours on the job

Less than 25 
Item

Frequently Sometimes Very Infrequently

or never

Takes walks in good weather

2

1

0

Works around house or apartment

2

1

0

Gardening in spring or summer

2

1

0

Takes part in sports other than golf,

Bowling, pool or billiards is mentioned 2

1

0

Other

2

1

0 